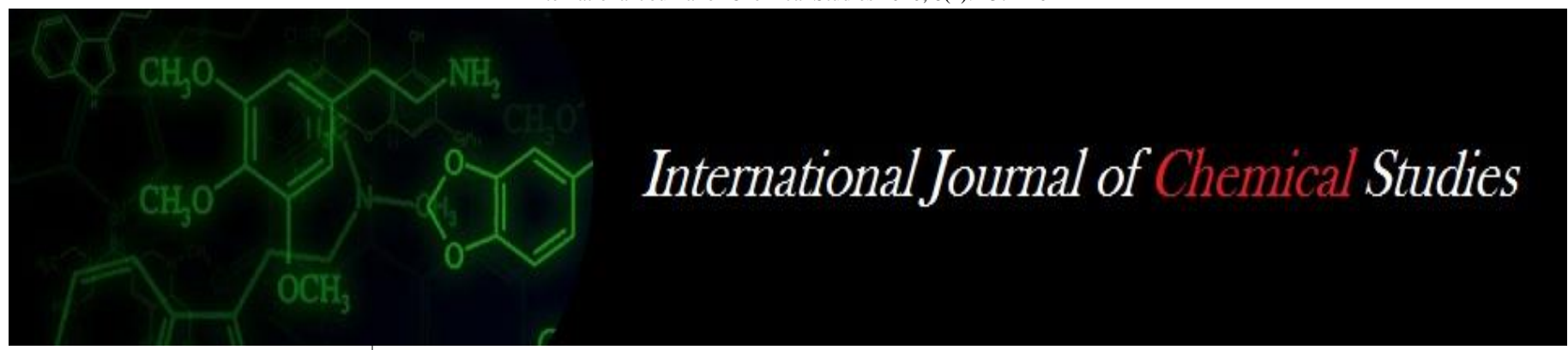

P-ISSN: 2349-8528

E-ISSN: 2321-4902

www.chemijournal.com

IJCS 2020; 8(2): 437-440

(C) 2020 IJCS

Received: 07-01-2020

Accepted: 09-02-2020

\section{Gonchikari Lokesh}

College of Horticulture,

Anantharajupeta, Dr. Y.S.R.

Horticultural University,

Andhra Pradesh, India

\section{Madhumathi}

College of Horticulture,

Anantharajupeta, Dr. Y.S.R.

Horticultural University,

Andhra Pradesh, India

\section{B Tanuja Priya}

College of Horticulture,

Anantharajupeta, Dr. Y.S.R.

Horticultural University,

Andhra Pradesh, India

\section{Lalitha Kadiri}

College of Horticulture,

Anantharajupeta, Dr. Y.S.R.

Horticultural University,

Andhra Pradesh, India
Corresponding Author: Gonchikari Lokesh

College of Horticulture, Anantharajupeta, Dr. Y.S.R. Horticultural University, Andhra Pradesh, India

\section{Effect of salicylic acid and potassium silicate on shelf life of mango (Mangifera indica L.) cv. Alphonso}

\author{
Gonchikari Lokesh, C Madhumathi, M Rama Krishna, B Tanuja Priya \\ and Lalitha Kadiri
}

DOI: https://doi.org/10.22271/chemi.2020.v8.i2g.8805

\begin{abstract}
An experiment was conducted at farmer's field, near College of Horticulture, Anantharajupeta, Andhra Pradesh during the year 2017-2018 under Dr. Y.S.R Horticultural University, to assess the effect of potassium silicate and salicylic acid on fruit shelf life in mango (Mangifera indica L.) cv. Alphonso. The experiment consisted of nine treatments viz. $\mathrm{T}_{1}$ (control), $\mathrm{T}_{2}$ (potassium nitrate @ 1\%), $\mathrm{T}_{3}$ (salicylic acid @ 100 ppm), $\mathrm{T}_{4}$ (salicylic acid @ 200 ppm), T5 (potassium silicate @ 0.1\%), T6 (potassium silicate @ $0.2 \%$ ), T7 (salicylic acid @ 100 ppm + potassium silicate@0.1\%), T8 (salicylic acid @ 0.2\% + potassium silicate@200 ppm), T9 (paclobutrazol @ $3 \mathrm{ml} \mathrm{m}^{-1}$ ). Seven years old mango orchard was selected for experiment and planted with spacing $7.5 \mathrm{~m}$ in square system. Results revealed that foliar application of salicylic acid @ $200 \mathrm{ppm}+$ potassium silicate @ $0.2 \%\left(\mathrm{~T}_{8}\right)$ found to enhance shelf life of fruits (15.10 days), marketable fruits percentage $(88.94 \%)$, firmness $\left(4.97 \mathrm{~kg} / \mathrm{cm}^{2}\right)$ and reduce physiological loss in weight during storage period.
\end{abstract}

Keywords: Mango, salicylic acid, physiological loss in weight, shelf life, firmness, TSS

\section{Introduction}

Mango (Mangifera indica L.) is one of the most important fruit crops of the tropics and subtropics that belongs to family Anacardiaceae, native to Indo-Burma region. It has been grown since long and leading fruit crop of India and is known as "King of fruits" due to its sweetness, richness of taste, huge variability, large production volume and a variety of end usage. Besides, having delicious taste, captivating flavour with multifarious colours, it is an excellent source of dietary nutrients and Vitamin A. It is grown in almost all parts of the world and India is considered as the largest mango producing country of the world, cultivated in an area of 2.26 million hectares with a production of 19.68 million metric tonnes (Anon., 2017) [1]. The area and production are highest in Andhra Pradesh with 0.33 million hectares and 3.16 million metric tonnes, respectively contributing 16 percent to the country's total production (Anon., 2017) ${ }^{[1]}$.

Salicylic acid belongs to phytohormone which classified as a phenylpropanoid compound and stimulated by biotic and abiotic stresses to induce defense responses. Moreover, it is also classified as an ethylene inhibitor (Gerailoo and Ghasemnezhad, 2011) ${ }^{[7]}$. Exogenous Salicylic acid application has been used to maintain postharvest quality, extend shelf-life, control diseases and allevative physiological disorders during storage (Asghari and Aghdam, 2010) ${ }^{[2]}$. Silicon has been reported as a beneficial nutrient, protecting plants against various diseases. It confers resistance to certain diseases are associated with the physical block created by the deposition of this element under the cuticle and on the epidermal cell wall or with the enhancement of defense mechanisms such as production of phenolic compounds, hence, increase lignification and promote cell wall strengthening to control many diseases in plant (Lopes et al., 2014) ${ }^{[10]}$. Foliar application of potassium nitrate leads to improves fruit quality in mango fruits (Yadav et al., 2017 and Patoliya et al., 2017) ${ }^{[20,13]}$. Shinde et al (2015) ${ }^{[16]}$ and Subbaiah et al. (2017) ${ }^{[18]}$ reported that paclobutrazol application in mango improves its fruit quality. So, based on the above research background apply salicylic acid, potassium silicate, potassium nitrate and paclobutrazol on mango plants for improving shelf life of fruits. 


\section{Materials and Methods}

The experiment was carried out at farmer's field, it was situated $2 \mathrm{~km}$ away from College of Horticulture, Anantharajupeta, YSR Kadapa (D), Dr. Y.S.R Horticultural University, Andhra Pradesh. The field is situated at an altitude of 162 meters (531 feet) above mean sea level and at $14.02^{\circ}$ North latitude and $79.33^{\circ}$ East longitude which falls under tropical zone with a normal rainfall of $966.1 \mathrm{~mm}$. The soil of the orchard selected is a red sandy loam with a $\mathrm{pH}$ of 7.1 and electrical conductivity of $0.24 \mathrm{dsm}^{-1}$. Soil contains $0.38 \%, 7.5$ $\mathrm{kg} \mathrm{ha}{ }^{-1}$, and $395 \mathrm{~kg} \mathrm{ha}^{-1}$ of organic carbon, available phosphorus and potassium contents, respectively. The experimental material consisted of 7 years old, well grown, uniform statured trees of mango cultivar 'Alphonso' (syn Khader). The trees were spaced at $7.5 \mathrm{~m}$ and planted in square system. In all, 27 uniform trees of 'Alphonso' were selected for experimentation. All cultural practices like fertilizer application, spraying of pesticides, fungicides and irrigation were uniformly practiced in experimental trees.

The experiment was laid out in Randomized Block Design with three replications and nine treatments namely, Control $\left(\mathrm{T}_{1}\right)$, Potassium nitrate @ 1\% $\left(\mathrm{T}_{2}\right)$, Salicylic acid @ 100 ppm $\left(\mathrm{T}_{3}\right)$, Salicylic acid @ 200 ppm $\left(\mathrm{T}_{4}\right)$, Potassium silicate @ 0.1\% ( $\left.\mathrm{T}_{5}\right)$, Potassium silicate@ 0.2\% ( $\left.\mathrm{T}_{6}\right)$, Salicylic acid@ 100 ppm + Potassium silicate @ 0.1\% ( $\left.\mathrm{T}_{7}\right)$, Salicylic acid @ 200 ppm + Potassium silicate @ 0.2\% ( $\left.\mathrm{T}_{8}\right)$, Paclobutrazol @ $3 \mathrm{ml} \mathrm{m}^{-1}\left(\mathrm{~T}_{9}\right)$. Paclobutrazol was applied as soil application at September first week and remaining all chemicals were applied as foliar spray, first at flower bud initiation stage (December first week), second at two weeks after fruit set (February second week).

In each treatment five fruits were taken for quality attributes. The firmness of the fruit was tested by means of a pocket penetrometer (FR-5120 Digital Fruit Firmness Tester). Physiological loss in weight of fruits was determined by weighing the fruits immediately after harvesting and was recorded as the initial fruit weight. There after they were weighed periodically at 3 days interval up to days of storage at ambient temperature which served as the final weight. The number of visibly sound and healthy fruits were counted and expressed as percentage over the total number of fruits during storage. Each fruit was thoroughly scrutinized for any visible symptoms of spoilage and shelf-life was considered when 30 per cent of the fruits shown over ripening or spoilage symptoms. The data were subjected to statistical analysis as per the method of Panse and Sukhatme, $1985^{[12]}$. The treatments means were compared by means of critical difference of 5 per cent level of probability.

\section{Results and Discussion}

Results in Table. 1 indicated that on the $3^{\text {rd }}$ day of storage, there is no significant difference in the physiological loss in weight (PLW) in treated trees including control. On the $6^{\text {th }}$ day of storage, PLW recorded in all treatments showed a significant difference over control. The PLW on the $6^{\text {th }}$ day of storage was minimum in fruits harvested from trees treated with salicylic acid@200 ppm + potassium silicate@0.2\% $\left(\mathrm{T}_{8}\right)(7.33 \%)$ which was statistically at par with salicylic acid @ $100 \mathrm{ppm}+$ potassium silicate @ 0.2\% ( $\left.\mathrm{T}_{7}\right)(7.57 \%)$. The same trend continued on the $9^{\text {th }}$ day of storage, where in salicylic acid $200 @$ ppm + potassium silicate @ 0.2\% $\left(\mathrm{T}_{8}\right)$ registered the lowest physiological loss in weight $(10.69 \%)$, while the highest physiological loss in weight (13.19\%) observed in control $\left(\mathrm{T}_{1}\right)$ it was comparable with the application of Paclobutrazol ( $\left.\mathrm{T}_{9}\right)(13.05 \%)$.

Table 1: Effect of salicylic acid and potassium silicate on Physiological loss in weight (\%) of mango (Mangifera indica L.) cv. Alphonso

\begin{tabular}{|c|c|c|c|c|c|}
\hline \multirow{2}{*}{ Treatments } & \multicolumn{5}{|c|}{ Physiological loss in weight (\%) } \\
\cline { 2 - 6 } & \multicolumn{4}{|c|}{ Days after harvest } \\
\cline { 2 - 6 } & $\mathbf{3}^{\text {rd }}$ & $\mathbf{6}^{\text {th }}$ & $\mathbf{9}^{\text {th }}$ & $\mathbf{1 2}^{\text {th }}$ & $\mathbf{1 5}^{\text {th }}$ \\
\hline $\mathrm{T}_{1}:$ Control & 3.01 & 8.41 & 13.19 & 16.88 & 18.73 \\
\hline $\mathrm{T}_{2}:$ Potassium nitrate @ 1\% & 2.90 & 7.82 & 11.34 & 15.34 & 17.37 \\
\hline $\mathrm{T}_{3}:$ Salicylic acid @ 100 ppm & 2.93 & 7.78 & 11.26 & 14.96 & 18.18 \\
\hline $\mathrm{T}_{4}:$ Salicylic acid @ 200 ppm & 2.91 & 7.64 & 11.44 & 14.85 & 18.13 \\
\hline $\mathrm{T}_{5}:$ Potassium silicate @ 0.1\% & 2.92 & 8.01 & 12.12 & 14.81 & 17.32 \\
\hline $\mathrm{T}_{6}:$ Potassium silicate @ 0.2\% & 2.87 & 7.90 & 11.66 & 13.96 & 17.28 \\
\hline $\mathrm{T}_{7}:$ Salicylic acid @ 100 ppm + Potassium silicate @ 0.1\% & 2.85 & 7.57 & 11.97 & 13.94 & 17.24 \\
\hline $\mathrm{T}_{8}:$ Salicylic acid @ 200 ppm + Potassium silicate @ 0.2\% & 2.82 & 7.33 & 10.69 & 13.68 & 17.21 \\
\hline $\mathrm{T}_{9}:$ Paclobutrazol @ 3 ml m $\mathrm{m}^{-1}$ & 2.94 & 8.17 & 13.05 & 15.88 & 18.00 \\
\hline S.Em. \pm & 0.05 & 0.08 & 0.10 & 0.29 & 0.15 \\
\hline C.D. at 5\% & $\mathrm{NS}$ & 0.25 & 0.30 & 0.86 & 0.44 \\
\hline
\end{tabular}

On $12^{\text {th }}$ day of storage, fruits from trees treated with salicylic acid@ 200 ppm + potassium silicate @ 0.2\% $\left(\mathrm{T}_{8}\right)$ recorded the lowest physiological loss in weight (13.68\%), which was statistically on par with the application of salicylic acid @ $100 \mathrm{ppm}$ + potassium silicate @ 0.1\% ( $\left.\mathrm{T}_{7}\right)(13.94 \%)$ and $\mathrm{T}_{6}$ (potassium silicate @ $0.2 \%)(13.96 \%)$. On $15^{\text {th }}$ day of storage, trees treated with salicylic acid @ 200 ppm + potassium silicate@0.2\% ( $\left.\mathrm{T}_{8}\right)$ showed the lowest physiological loss in weight $(17.21 \%)$ in fruits which was statistically comparable with $\mathrm{T}_{7}$ (salicylic acid @ 100 ppm + potassium silicate @ $0.1 \%)(17.24 \%), \mathrm{T}_{6}$ (potassium silicate @ 0.2\%) (17.28\%), $\mathrm{T}_{5}$ (potassium silicate @ 0.1\%) (17.32\%) and $\mathrm{T}_{2}$ (potassium nitrate@1\%) (17.37\%). At all the stages of storage, fruits from untreated trees registered a significantly higher physiological loss in weight $(3.01,8.41,13.19,16.88$ and
$18.73 \%$ on $3^{\text {rd }}, 6^{\text {th }}, 9^{\text {th }}, 12^{\text {th }}$, and $15^{\text {th }}$ day of storage, respectively) as compared to sprayed trees.

The perusal of data in Table. 2 indicated that highest fruit firmness $\left(4.97 \mathrm{~kg} / \mathrm{cm}^{2}\right)$ was recorded with the spray of salicylic acid@200 ppm + potassium silicate @ 0.2\% $\left(\mathrm{T}_{8}\right)$, which was statistically significant than all remaining treatments. Fruits harvested from untreated trees exhibited the lowest firmness $\left(3.11 \mathrm{~kg} / \mathrm{cm}^{2}\right)$. The maximum shelf life (15.10) was recorded in treatment with salicylic acid @ 200 ppm + potassium silicate @ $0.2 \% \quad\left(\mathrm{~T}_{8}\right)$, which was significantly superior over other treatments including control. Moreover, the minimum shelf life (12.84 days) of fruits was noticed in control $\left(\mathrm{T}_{1}\right)$. There was a significant improvement among the treatments regarding percent marketable fruits as compared to control. Maximum percentage of marketable 
fruits $(88.94 \%)$ was observed in treatment $\mathrm{T}_{8}$ (salicylic acid @ 200 ppm + potassium silicate @ 0.2\%). However, minimum marketable fruits percentage (62.50\%) was observed in control $\left(\mathrm{T}_{1}\right)$.

The results showed that foliar application of salicylic acid and potassium silicate alone or in combination had a significant effect on maintaining higher firmness in mango fruits. Increase in fruit firmness with salicylic acid might be due to decrease in the activity of cell wall degrading enzymes like cellulose, polygalacturonase, and xylanase (Srivastava and Dwivedi, 2000) ${ }^{[17]}$. Salicylic acid also interferes with biosynthesis and/or action of ethylene (Raskin, 1992) ${ }^{[14]}$. Similar effects of salicylic acid on maintenance of higher fruit firmness was also been reported by Reddy et al. (2016) ${ }^{[15]}$ in mango, Barakat et al. (2015) ${ }^{[4]}$, Barzinji et al. (2017) ${ }^{[5]}$ in pear and Deljou et al. (2017) ${ }^{[6]}$ in apple. In the same context of the obtained data in the present study, Babak and Majid (2011) ${ }^{[3]}$ reported that silicon lowers ethylene production and forms complexes with organic compounds in the cell wall of epidermal cells, therefore imparting resistance against degrading enzymes. Mohamed et al. (2017) ${ }^{[11]}$ also reported improvement of fruit firmness with silicon in mango. Potassium silicate also improves the shelf life of fruits because this may have minimized the physiological loss in weight and ultimately increased shelf life. A similar increase in shelf life and decrease in physiological loss in weight of fruits with silicon application were reported by Mohamed et al. (2017) ${ }^{[11]}$, Vidya et al. (2014) ${ }^{[19]}$ in mango and Lalithya et al. (2013) ${ }^{[9]}$ in sapota and Hanumanthaiah et al. (2015) ${ }^{[8]}$ in banana.

Table 2: Effect of potassium silicate and salicylic acid on shelf life of mango (Mangifera indica L.) cv. Alphonso

\begin{tabular}{|c|c|c|c|}
\hline Treatments & Firmness (kg/cm $\left.{ }^{2}\right)$ & Shelf life (days) & Marketable fruits (\%) \\
\hline $\mathrm{T}_{1}:$ Control & 3.11 & 12.84 & 62.50 \\
\hline $\mathrm{T}_{2}:$ Potassium nitrate @ 1\% & 3.61 & 14.10 & 77.79 \\
\hline $\mathrm{T}_{3}:$ Salicylic acid @ 100 ppm & 3.62 & 13.48 & 76.33 \\
\hline $\mathrm{T}_{4}:$ Salicylic acid @ 200 ppm & 3.74 & 13.57 & 85.55 \\
\hline $\mathrm{T}_{5}:$ Potassium silicate @ 0.1\% & 3.98 & 13.84 & 79.40 \\
\hline $\mathrm{T}_{6}:$ Potassium silicate @ 0.2\% & 4.11 & 14.06 & 82.23 \\
\hline $\mathrm{T}_{7}:$ Salicylic acid @ 100 ppm + Potassium silicate @ 0.1\% & 4.60 & 14.25 & 85.25 \\
\hline $\mathrm{T}_{8}:$ Salicylic acid @ 200 ppm + Potassium silicate @ 0.2\% & 4.97 & 15.10 & 88.94 \\
\hline $\mathrm{T}_{9}:$ Paclobutrazol @ 3 ml m ${ }^{-1}$ & 3.58 & 13.38 & 66.48 \\
\hline S.Em. \pm & 0.14 & 0.27 & 0.56 \\
\hline C.D. at 5\% & 0.43 & 0.80 & 1.69 \\
\hline
\end{tabular}

\section{Conclusion}

Based on the present investigation it can be concluded that minimum physiological loss in weight at $12^{\text {th }}$ and day $(13.68 \%)$ and $15^{\text {th }}$ day $(17.21 \%)$ was observed in the fruits harvested from the trees treated with salicylic acid@200 ppm + potassium silicate @ 0.2\% $\left(\mathrm{T}_{8}\right)$. Further, the highest shelf life of fruits (15.10 days) and marketable fruits percentage (88.94) during storage were recorded in treatment $\mathrm{T}_{8}$ (salicylic acid @ $200 \mathrm{ppm}+$ potassium silicate @ 0.2\%).

\section{References}

1. Anonymous. State wise area, production and productivity of mango. National Horticulture Board, Indian Horticulture Database, 2016-17.

2. Asghari M, Aghdam MS. Impact of salicylic acid on post-harvest physiology of horticultural crops. Trends Food Science and Technology. 2010; 21:502-509.

3. Babak J, Majid R. Carnation flowers senescence as influenced by nickel, cobalt and silicon. Journal of Biology and Environmental Science. 2011; 5(15):147152.

4. Barakat MR, Mohsen AT, Mohamed AA. Effect of some natural oils and salicylic acid on fruit quality of Valencia orange during storage. Journal of Horticultural Science and Ornamental Plants. 2015; 7(2):66-70.

5. Barzinji IMA, Ahmed TA, Fadhil N. Effects of foliar spraying with salicylic acid on some quantity and quality characteristics of pear fruits. Journal of Advances in Agriculture. 2017; 2(7):1064-1070.

6. Deljou MH, Ashari ME, Sarikhani H. Effect of pre and postharvest salicylic acid treatments on quality and antioxidant properties of red delicious apples during cold storage. Advances in Horticulture Science. 2017; 31(1):31-38.
7. Gerailoo S. Ghasemnezhad. Effect of salicylic acid on antioxidant enzyme activity and petal senescence in 'Yellow Island' cut Rose flowers. Journal of Fruit Ornamental Plant Research. 2011; 19:183-193.

8. Hanumanthaiah MR, Kulapatihipparagi, Vijendrakumar RC, Renuka DM, Kirankumar K, Santhosha KV. Effect of soil and foliar application of silicon on fruit quality parameters of banana cv. Neypoovan under hill zone. Plant Archives. 2015; 15(1):221-224.

9. Lalithya KA, Hipparagi H, Thippeshappa GN, Vishnuvardhana. Influence of silicon and micronutrients on yield and quality traits of sapota cv. Kalipatti under hill zone. Crop Research (Hisar). 2013; 46(1-3):150-152.

10. Lopes UP, Zambolim L, Costa H, Pereira OL, Finger FL. Potassium silicate and chitosan application for gray mold management in strawberry during storage. Crop protection. 2014; 63:103-106.

11. Mohamed MAA, El-Khalek AFA, Elmehrat HG. Preharvest potassium silicate, chitosan and calcium chloride application improves mango fruits (Zebda cv.) quality and storability. Egypt Journal of Horticulture. 2017; 44(1):17-32.

12. Panse VG, Sukhatme PV. Statistical methods for agricultural workers. ICAR, New Delhi, 1985.

13. Patoliya RM, Tandel BM, Unnati A, Patil SJ, Hiralal C. Response of foliar spray of different chemicals on yield and quality of dashehari mango under ultra-high density plantation. International Journal of Chemical Studies. 2017; 5(4):1495-1497.

14. Raskin I. Role salicylic acid in plants. Annual. Review of Plant Physiology and Plant Molecular Biology. 1992; 43:439-463.

15. Reddy VR, Sharma SRR, Srivastav M, Kaur C. Effect of pre-harvest application of salicylic acid on postharvest 
behaviour of Amrapali mango fruits during storage. Indian Journal of Horticulture. 2016; 73(3):405-409.

16. Shinde VK, Manjarekar RG, Kadam CS, Dubale JJ. Response of Paclobutrazol application time on flowering, fruiting and yield of mango cv. Alphonso. Remarketing. 2015; 1(8):1-4.

17. Srivastava MK, Dwivedi UN. Delayed ripening of banana fruit by salicylic acid. Plant Science. 2000; 158:87-96.

18. Subbaiah KV, Reddy NN, Reddy MLN. Effect of paclobutrazol and other chemicals on yield and quality of mango cv. Banganpalli. International Journal of Science, Environment. 2017; 6(3):1809-1819.

19. Vidya A, Swamy GSK, Prakash NB, Jagadeesh RC, Jagadesh SL, Ganadharappa PM et al. Effect of preharvest sprays of nutrients on the physic-chemical characters in mango (Mangifera indica) cv. Mallika. Mysore Journal of Agricultral Sciences. 2014; 48(4):529533.

20. Yadav RK, Sarolia DK, Kaushik RA, Devra NS, Yadav GL. Response of mango (Mangifera indica L.) culttivars to agro-chemicals with respect to physical parameters. International Journal of Current Microbiology and Applied Sciences. 2017; 66(6):160-164. 